19 Jones G, Ngyen T, Sambrook PN, Kelly PJ, Gilbert C, Eisman JA. Symptomatic fracture incidence in elderly men and women: the Dubbo osteoporosis epidemiologic study (DOES). Osteoporosis Int 1994;4: $277-82$.

20 Lauritzen JB, Schwarz P, Lund B, Mcnair P, Transpøl I. Changing incidence and residual lifetime risk of common osteoporosis-related fractures. Osteoporosis Int 1993;3:127-32.

21 Salmela R, Koistinen V. Coverage and accuracy of the hospital discharge register (in Finnish). Hospital 1987;49:480-2.

22 Keskimäki I, Aro S. Accuracy of data on diagnosis, procedures and accidents in the Finnish hospital discharge register. Int J Health Sci 1991;2: $15-21$.

23 Lüthje P, Nurmi I, Kataja M, Heliövaara M, Santavirta S. Incidence of pelvic fractures in Finland in 1988. Acta Orthop Scand 1995;66:245-8.

24 Falconer DS. Introduction to quantitative genetics. Harlow, Essex: Longman, 1981.

25 Emery EM. Methodology in medical genetics: an introduction to statistical meth ods. Edinburgh: Churchill Livingstone, 1976.

26 Heath AC, Neale MC, Hewitt JK, Eaves LJ, Fulker DW. Testing structural equation models for twin data using LISREL. Behav Genet 1989;19:9-35.

27 Slemenda CW, Christian JC, Williams CJ, Norton JA, Johnston CC J Genetic determinant of bone mass in adult women: a reevaluation of the twin model and the potential importance of gene interaction on heritability estimates.J Bone Miner Res 1991;6:561-7.

28 Spector TD, Cicuttini F, Baker J, Loughlin J, Hart D. Genetic influences on osteoarthritis in women: a twin study. BMJ 1996;312:940-4.

29 Neale MC, Eaves LJ, Kendler KS. The power of the classical twin study to resolve variation in threshold traits. Behav Genet 1994:24:939-58.
30 Cummings SR, Nevitt MC, Browner WS, et al. Risk factors for hip fracture in white women. $N$ Engl J Med 1995;332:767-73.

31 Fox KM, Cummings SR, Powell-Threets K, Stone K for the Study of Osteoporotic Fractures Research Group. Family history and risk of osteoporotic fracture. Osteoporos Int 1998;8:557-62.

32 Nevitt MC, Cummings SR. Type of fall and risk of hip and wrist fractures: the study of osteoporotic fractures. J Am Geriatr Soc 1993;41:1226-34.

33 Greenspan SL, Myers ER, Maitland LA, Resnick NM, Hayes WC. Fall severity and bone mineral density at risk factors for hip fracture in ambulatory elderly. JAMA 1994;271:128-33.

34 Dargent-Molina P, Favier F, Grandjean H, et al. Fall-related factors and risk of hip fracture: the EPIDOS prospective study. Lance $1996: 348: 145-9$.

35 Marshall D, Johnell O, Wedel H. Meta-analysis of how well measures of bone mineral density predict occurrence of osteoporotic fractures. $B M J$ 1996;312:1254-9.

36 Nguyen TV, Eisman JA, Kelly PJ, Sambrook PN. Risk factors for osteoporotic fractures in elderly men. Am J Epidemiol 1996;144:255-63.

37 De Laet CEDH, van Hout BA, Burger H, Hofman A, Pols HA. Bone density and risk of hip fracture in men and women: cross sectional analysis. BMJ 1997;315:221-5

38 Tinetti ME, Baker DI, McAvay G, Claus EB, Garrett P, Gottschalk M, et al. A multifactorial intervention to reduce the risk of falling among elderly people living in the community. N Engl J Med 1994;331:821-7.

39 Lauritzen JB, Petersen MM, Lund B. Effect of external hip protectors on hip fractures. Lancet 1993;341:11-3.

(Accepted 24 August 1999)

\title{
High penetrance, overweight, and glucocorticoid receptor variant: case-control study
}

\author{
Ruby C Y Lin, William Y S Wang, Brian J Morris
}

A possible link between the glucocorticoid receptor gene (GRL, 5q31-q32) and overweight has been suggested in a study of 42 families with morbid obesity. ${ }^{1}$ Data from another small study-of pairs of siblings-although not significant, showed a trend towards similar body mass index (weight $(\mathrm{kg}$ )/ (height $\left.(m)^{2}\right)$; difference $=2.4$ ) for 20 pairs sharing similar alleles compared with 19 pairs having discordant alleles (difference $=3.5$ ). ${ }^{2}$ An Asn363Ser variant, caused by a single nucleotide difference (A1218G) in exon 2 of GRL has since shown an association with increased sensitivity to glucocorticoids. ${ }^{3}$ Because of the predisposition to a rise in body mass index that this increased sensitivity should cause, we tested this variant for association with overweight in two groups of non-diabetic white subjects of British descent.

\section{Methods and results}

All participants lived in or near Sydney and had responded to requests to take part in a study that involved DNA testing. Because of the interaction between obesity and hypertension we selected subjects on the basis of a positive or negative family history of hypertension and tested them separately. Group 1 was recruited from donors at the Sydney Blood Bank and comprised 195 subjects who were normotensive offspring of two normotensive parents. Group 2 comprised 124 subjects recruited by public advertising for people with essential hypertension whose parents also had hypertension. Mean body mass index was 26 (SD 4) in group 1 and 26 (SD 5) in group 2; mean age was 48 (SD 10) years and 52 (SD 12) years respectively; percentage of male participants was $57 \%$ and $49 \%$ respectively; and blood pressure was 120 (SD 11)/73 (SD 8) $\mathrm{mm} \mathrm{Hg}$ and 173 (SD 24)/110 (SD 17) mm Hg respectively.

Each group was divided into two subgroups: lean (body mass index $\leq 25)$ and overweight (>25). Genotyping was performed on leucocyte DNA using polymerase chain reaction primers described previously ${ }^{4}$ and Tsp509I digestion of polymerase chain reaction products, which gave a band of 134 base pairs for the Asn363 variant and 153 base pairs for the Ser363 variant, together with a band of 95 base pairs for both.

The frequency of the Ser363 variant (number of Ser363 alleles divided by total number of alleles) in each group was similar ( $7.4 \%$ (95\% confidence interval $4.8 \%$ to $10.0 \%)$ in group $1 v 6.0 \%(3.1 \%$ to $9.0 \%)$ in group 2), with $12.3 \%$ ( $7.7 \%$ to $16.9 \%$ ) in group 1 being carriers (that is, they had one or two alleles) and 10.5\% $(5.1 \%$ to $15.9 \%)$ in group 2 . In participants with body mass index $\leq 25$ the Ser363 allele was rare $(1.8 \%$ in group 1 and $0 \%$ in group 2). All Ser/Ser homozygotes were overweight, as were all Asn/Ser heterozygotes in group 2 and $80 \%$ of Asn/Ser heterozygotes in group 1 (table). Association with overweight was highly significant (table), with overall penetrance in participants with the Ser363 variant being 83\% in group 1 and $100 \%$ in group 2. Consistent with this, the higher the body mass index, the more likely the subject was to have the Ser363 variant (table).

\section{Comment}

We found that the Ser363 variant of the glucocorticoid receptor confers a virtually absolute likelihood of being overweight-unlike most markers
Gene Laboratory, Department of Physiology and Institute for Biomedical Research, Building F13, University of Sydney, Sydney,

NSW 2006

Australia

Ruby C Y Lin

PhD student

William Y S Wang master of medicine student

Brian J Morris professor of physiology

Correspondence to: B J Morris brianm@physiol. usyd.edu.au

BMJ 1999;319:1337-8 
Association of Ser363 allele of GRL gene with overweight and body mass index

\begin{tabular}{|c|c|c|c|c|}
\hline & & Genotype & & \\
\hline & Asn/Asn & Asn/Ser & Ser/Ser & Significance \\
\hline Frequency of genotype & & & & \\
\hline Group 1: & & & & \\
\hline Body mass index $\leqslant 25$ & 107 & 4 & 0 & $\chi^{2}=18.8(P=0.0001)$ \\
\hline Body mass index >25 & 64 & 15 & 5 & \\
\hline Group 2: & & & & \\
\hline Body mass index $\leqslant 25$ & 63 & 0 & 0 & $\chi^{2}=15.0(\mathrm{P}<0.0001)$ \\
\hline Body mass index >25 & 48 & 11 & 2 & \\
\hline Mean (SD) body mass in & & & & \\
\hline Group 1 & $25.7(4.3) ; n=171$ & $27.6(4.0) ; n=19$ & $28.2(3.2) ; n=5$ & $\mathrm{~F}=2.5^{\star}(\mathrm{P}=0.082)$ \\
\hline Group 2 & $25.6(4.1) ; n=111$ & $29.9(2.4) ; n=11$ & $38.0(11) ; n=2$ & $F=13.9^{\star} \quad(P<0.0001)$ \\
\hline
\end{tabular}

*By one way analysis of variance.

of overweight, which confer only a slight increase in likelihood. The allele is relatively common. Given the difference in response to various modalities of intervention according to genetic propensity to increased body mass index for a variant in another gene, ${ }^{5}$ our finding of almost complete penetrance of Ser363 genotypes to an overweight phenotype suggests that use of this marker could be important in clinical management.

Contributors: RCYL performed the genotyping, WYSW provided guidance with study design and performed statistical analyses, and BJM conceived the idea for the project and directed the research. All authors contributed to the drafting of the paper. BJM will act as guarantor.

Funding: The study was supported by a grant from the National Health and Medical Research Council of Australia.

\section{Competing interests: None declared.}

Clement K, Philippi A, Jury C, Pividal R, Hager J, Demenais F, et al. Candidate gene approach of familial morbid obesity: linkage analysis of the glucocorticoid receptor gene. Int J Obesity 1996;20:507-12.

2 Takami S, Wong ZYH, Stebbing M, Harrap SB. Linkage analysis of glucocorticoid and $\beta_{2}$-adrenergic receptor genes with blood pressure and body mass index. Am J Physiol 1999;276:H1379-84

3 Huizenga NATM, Koper JW, deLange P, Pols HAP, Stolk RP, Burger H, et al. A polymorphism in the glucocorticoid receptor gene may be associated with increased sensitivity to glucocorticoids in vivo. J Clin Endocrin Metab 1998;83:144-51.

4 Koper JW, Stolk RP, de Lange P, Huizengo NATM, Molijn G-J, Pols HAP, et al. Lack of association between five polymorphisms in the human glucocorticoid receptor gene and glucocorticoid resistance. Hum Genet 1997;99:663-8.

5 Meirhaeghe A, Helbecque N, Cottel D, Amouyel P. $\beta_{2}$-adrenoceptor gene polymorphism, body weight, and physical activity. Lancet 1999;353:895-6.

(Accepted 30 July 1999)
Institute of Public Health, University of Cambridge, Cambridge CB2 2SR

R L Himsworth professor of health research and development

continued over

BMJ 1999;319:1338-9

website

\section{extra}

An additional figure appears on the BMJ's website

www.bmj.com
The use of health services rises substantially with increasing age. ${ }^{1}$ Although this is commonly assumed to be a consequence of longevity, the chief determinants of lifetime use of health services, irrespective of age at death, may be the antecedents of death, ${ }^{2}$ and increased use by elderly people may result from their being closer to death than young people. We studied time in hospital in the final 15 years of life (as a proxy for major morbidity) and related this to age at death.

\section{Subjects, methods, and results}

We used data from the Oxford record linkage study, which includes death certificates and statistical records of NHS hospital admissions for part of southern England (population 1.9 million). ${ }^{3}$ We chose 1991 as the base year because the data provided a retrospective period of 15 years and because from 1992, the system of providing mortality data to the record linkage study changed. We included all NHS admissions in the 15 years before death, of residents of the region who died in 1991 at 45 years and over (excluding those in the specialties of psychiatry and obstetrics). The data were grouped separately by sex and by age at death at 45-59 years and in five year age groups thereafter to $90-94$ (too few deaths occurred at $\geq 95$ years for worthwhile analysis). We analysed time in hospital for these age groups in each of the 15 years before death and calculated centile distributions of "heaviness" of hospital use in each group.

There were 18524 deaths (men, 9156; women, 9368). Time in hospital in the 15 years before death rose with increasing age-median days in hospital rose in men from 11 days at age 45-59 at death to 26 days at age 90-94 at death and in women from 18 days at age $45-59$ to 32 days at age 90-94. These increases in the median represent an extra half day in hospital in the 15 years before death for each additional year of life beyond age 60 .

Time in hospital did not accumulate uniformly over the 15 years before death. Generally, hospital admissions either occurred in the years immediately before death and increased in the final year of life or were confined to that last year. The total time spent in 